\title{
Blood hyperreosinophilia: A diagnostic challenge
}

\author{
Gülden PAÇACI \\ ÇETIN $^{1}$ (ID) \\ Mehmet KÖSE ${ }^{2}(I D)$

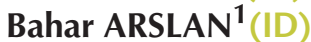 \\ İnsu YILMAZ ${ }^{1}$ (ID)
}

${ }^{1}$ Division of Immunology and Allergy, Department of Chest Diseases, Erciyes University Faculty of Medicine, Kayseri, Turkey

${ }^{1}$ Erciyes Üniversitesi Tıp Fakültesi, Gögüs Hastalıkları Anabilim Dalı, Immünoloji ve Alerji Bilim Dalı, Kayseri, Türkiye

2 Department of Pediatric Chest Diseases, Erciyes University Faculty of Medicine, Kayseri, Turkey

${ }^{2}$ Erciyes Üniversitesi Tıp Fakültesi, Pediatrik Göğüs Hastalıkları Anabilim Dalı, Kayseri, Türkiye
Cite this article as: Paçacı Çetin G, Köse M, Arslan B, Yılmaz i. Blood hyperreosinophilia: a diagnostic challenge. Tuberk Toraks 2021;69(3):408-415.

Address for Correspondence (Yazışma Adresi)

\section{Dr. Gülden PAÇACI ÇETIN}

Division of Immunology and Allergy,

Department of Chest Diseases, Erciyes

University Faculty of Medicine

KAYSERI - TURKEY

e-mail: drguldenp@gmail.com

CCopyright 2021 by Tuberculosis and Thorax.

Available on-line at www.tuberktoraks.org.com

\begin{abstract}
Blood hyperreosinophilia: A diagnostic challenge

A very detailed differential diagnosis is necessary to investigate the causes of blood hypereosinophilia. In the differential diagnosis of hypereosinophilia with pulmonary involvement, primary and secondary eosinophilic lung diseases should be kept in mind, and more specific diagnoses should be considered in those with a history of nasal polyposis and asthma. Here, it was aimed to present a case of organ-limited hypereosinophilia with asthma and nasal polyposis.
\end{abstract}

Key words: Hypereosinophilia; chronic eosinophilic pneumonia; eosinophilic asthma; chronic rhinosinusitis; nasal polyposis

ÖZ

\section{Hipereozinofili: Tanısal zorluklar}

Hipereozinofilinin nedenlerini araştırmak için çok detaylı bir ayırıcı tanı gereklidir. Pulmoner tutulumlu hipereozinofili ayırıc tanısında primer ve sekonder eozinofilik akciğer hastalıkları akılda tutulmalı, nazal polipozis ve astım öyküsü olanlarda daha spesifik tanılar düşünülmelidir. Bu olguda astımIı ve nazal polipozisli organ sınırlı bir hipereozinofili olgusunu sunmak istedik.

Anahtar kelimeler: Hipereozinofili; kronik eozinofilik pnömoni; eozinofilik astım; kronik rinosinüzit; nazal polip 
Paçacı Çetin G, Köse M, Arslan B, Yılmaz i.

\section{INTRODUCTION}

Eosinophilic asthma is increasingly recognized as one of the most severe and difficult-to-treat asthma phenotype (1-3). Eosinophilic asthma with chronic rhinosinusitis and/or nasal polyposis (EA-CRS/NP) is a subphenotype of eosinophilic asthma and is more common in the adulthood $(4,5)$. Blood eosinophil levels are shown to be highly elevated in patients with EA-CRS/NP and have the potential for tissue infiltration. More than 1500 cells/ $\mu \mathrm{l}$ is accepted as eosinophilia with the potential for tissue infiltration and hypereosinophilia (6). We noticed that in some patients with EA-CRS/NP, this potential pulmonary tissue infiltration could be demonstrated by radiological imaging. We defined this group as "Eosinophilic Asthma with chronic Rhinosinusitis and/or nasal polyposis with Radiological findings related to blood eosinophilia (EARR)" (7). Eosinophilic lung disease comprises a rare group of heterogeneous diffuse parenchymal lung diseases characterized by marked accumulations of infiltrating eosinophils in the alveolar space and the interstitium (8). Chronic eosinophilic pneumonia (CEP) is a rare disorder among diffuse parenchymal lung diseases and may be accompanied by nasal polyps (9). In this study, it was aimed to report an adolescent patient of EARR + CEP overlap, making the differential diagnosis, eosinophilic lung diseases, a diverse group of pulmonary disorders associated with peripheral and tissue eosinophilia.

\section{CASE PRESENTATION}

A 15-year-old male patient, who had been healthy until the age of 12, had a cough and shortness of breath three years before, and pneumonia was detected on his admission. The patient with a prolonged cough after pneumonia was diagnosed with asthma due to his history and positive reversibility and obstructive pattern in respiratory function tests. There was a frequent need for oral corticosteroid (OCS) use due to uncontrolled asthma in the last three years. While skin prick test was negative, an increase in eosinophilia was detected in the exacerbation periods of asthma. Clinical improvement and decrease in eosinophilia were found after systemic steroids (40 mg methylprednisolone for a short time for five days)( Table 1). In the last three years, some of the asthma exacerbations had been diagnosed as pneumonia and treated with antibiotic treatments and with systemic steroids (methylprednisolone 40 mg 5 days) except one (Table 1). The tests performed

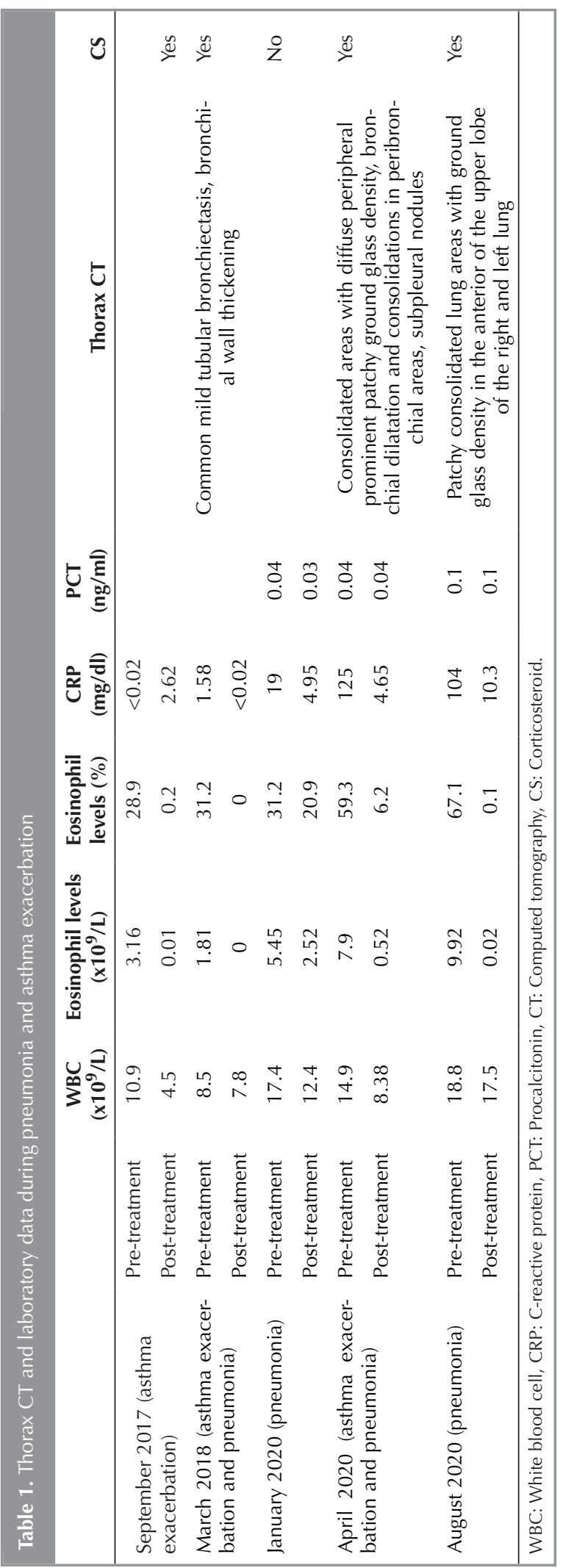

Tuberk Toraks 2021;69(3):408-415 
for immunodeficiency and hypereosinophilia during the illness period about 30 months due to his frequent pneumonia history and thorax $\mathrm{CT}$ findings are shown in Table 2. The August 2020 Thorax CT image is shown in Figure 1A.

Nasal steroid + antihistaminic and low-dose systemic steroid (5 mg prednisolone for three months) were started due to the detection of nasal polyposis in Paranasal Sinus Computed Tomography (PNSCT) (Figure 1B) but withdrawn due to frequent rhinosinusitis symptoms, and the inability to smell and nasal congestion affecting the quality of life. Nasal polypectomy was performed in 2019 because nasal polyp symptoms did not regress in the patient whose asthma was under control with low dose OCS in addition to the high dose inhaled corticosteroid (ICS) + long-acting $\beta 2$-agonist (LABA) + leukotriene receptor antagonist (LTRA) treatment he received for his asthma. He was most recently hospitalized in August 2020 due to the etiology of pneumonia and eosinophilia. Since an immunosuppressive state could not be ruled out due to fever $\left(38.6^{\circ} \mathrm{C}\right)$, and because of high C-reactive protein (CRP), eosinophilia and total IgE elevation were attributed to an immunosuppressive state, and meropenem and fluconazole were initiated. The patient, whose cough, shortness of breath, and wheezing continued under this treatment, was referred to our clinic because he had a high fever $\left(38.2^{\circ} \mathrm{C}\right)$ and eosinophils did not decrease. The results of the tests performed for the etiology of hypereosinophilia in August 2020 are summarized in Table 3. In the microscopic examination of the BAL sample, $79 \%$ of eosinophils were found (Figure 2).

Table 2. Detailed examination results after frequent pneumonia

\begin{tabular}{|c|c|c|c|}
\hline & & March 2018 & August 2020 \\
\hline \multirow[t]{3}{*}{ Alpha-1 antitrypsin } & & $223 \mathrm{mg} / \mathrm{dl}(90-200)$ & \\
\hline & CD45 & $99 \%$ & $100 \%$ \\
\hline & CD3 & $67 \%$ & $58 \%$ \\
\hline \multirow[t]{3}{*}{ Lymphocyte subgroups } & CD4 & $37.5 \%$ & $29 \%$ \\
\hline & CD8 & $23 \%$ & $20.6 \%$ \\
\hline & CD19 & $23.2 \%$ & $24.6 \%$ \\
\hline \multicolumn{2}{|l|}{$\lg A$} & $166 \mathrm{mg} / \mathrm{dl}(85-220)$ & 237 mg/dl (85-220) \\
\hline \multicolumn{2}{|l|}{$\lg M$} & 137 mg/dl (75-197) & 129 mg/dl (75-197) \\
\hline \multicolumn{2}{|l|}{$\lg G$} & 1000 mg/dl (800-1900) & $1242 \mathrm{mg} / \mathrm{dl}(800-1900)$ \\
\hline \multicolumn{2}{|l|}{$\lg E$} & $1010 \mathrm{IU} / \mathrm{ml}(0-200)$ & $3229 \mathrm{IU} / \mathrm{ml}(0-200)$ \\
\hline \multicolumn{2}{|l|}{ BAL cytology } & & \%79 eosinophil \\
\hline \multicolumn{2}{|l|}{ BAL culture } & & Normal flora elements \\
\hline \multicolumn{2}{|l|}{ Sputum culture } & & Normal flora elements \\
\hline \multicolumn{2}{|l|}{ ANCA } & & Negative \\
\hline \multicolumn{2}{|l|}{ Aspergillus specific IgE } & & Negative \\
\hline \multicolumn{2}{|l|}{ Skin prick test } & & Negative \\
\hline \multicolumn{2}{|l|}{ Vitamin B12 } & & 276 \\
\hline \multicolumn{2}{|l|}{ Uric acid } & & 4.1 \\
\hline \multicolumn{2}{|l|}{$\mathrm{ECHO}$} & & Negative \\
\hline \multicolumn{2}{|l|}{ Troponin } & & 0.001 \\
\hline \multicolumn{2}{|c|}{ Stool test for parasite (3 times) } & Negative & Negative \\
\hline \multicolumn{2}{|l|}{ Hepatosplenomegaly } & & Negative \\
\hline \multicolumn{2}{|l|}{ PGDFR $\alpha$} & & Negative \\
\hline \multicolumn{2}{|l|}{ JAK2 } & & Negative \\
\hline
\end{tabular}




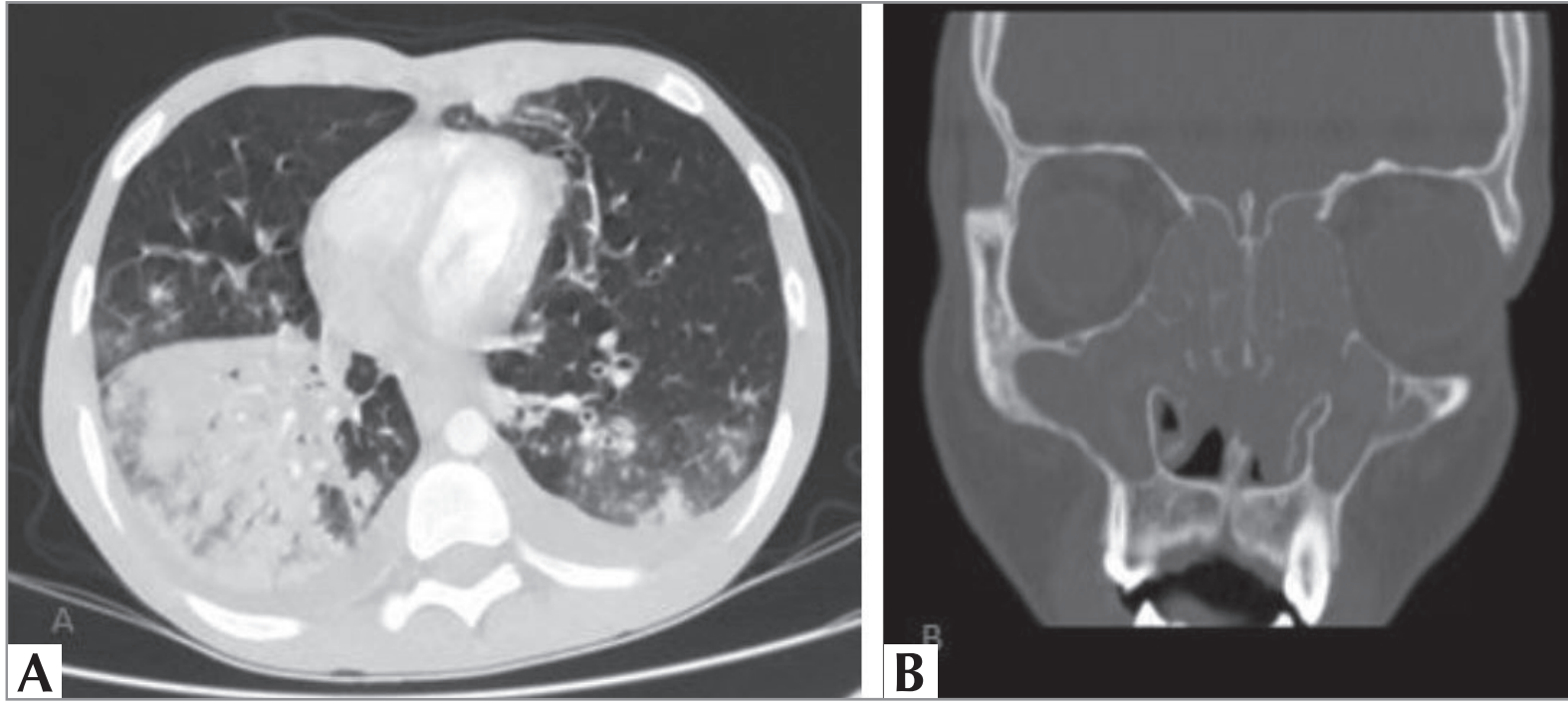

Figure 1. A. Thorax CT (August 2020) and B. Paranasal Sinus CT (September 2019).

Table 3. The properties of CEP and EARR

\begin{tabular}{|c|c|c|}
\hline & EARR & CEP \\
\hline Age, years & $35-55$ & $30-50$ \\
\hline Female gender & Dominant & Dominant \\
\hline Asthma & Yes & About half \\
\hline Asthma severity & Severe & Moderate \\
\hline Atopy & Low & High \\
\hline Nasal polyp & Yes & Rare \\
\hline Smoking & Low & Low \\
\hline Fever, weight loss & None & Usually \\
\hline ESR & Usually normal & Usually high \\
\hline CRP & Usually normal & Usually high \\
\hline ANCA & Negative & Negative \\
\hline High blood eosinophil level & Yes & Yes \\
\hline High total IgE level & Yes & Yes \\
\hline Thorax CT & $\begin{array}{l}\text { Ground-glass opacities, } \\
\text { Centrilobular nodules }\end{array}$ & $\begin{array}{l}\text { Airspace consolidation, } \\
\text { ground glass attenuations }\end{array}$ \\
\hline Response to systemic steroid & Very good & Very good \\
\hline Conversion to systemic disease & Rare (EARR plus= idiopathic HES phenotype) & Rare (EGPA or idiopathic HES) \\
\hline
\end{tabular}

The results of immunophenotyping by flow cytometric examination made from peripheral blood are shown in Figure 3.

Primary and secondary immunodeficiencies and secondary and other primary causes of eosinophilic lung diseases were ruled out. The patient was diagnosed with the eosinophilic asthma phenotype, called EARR in the literature, and CEP overlap, a disease with organ-limited hypereosinophilia localized in the respiratory tract. Forty-eight mg methylprednisolone 


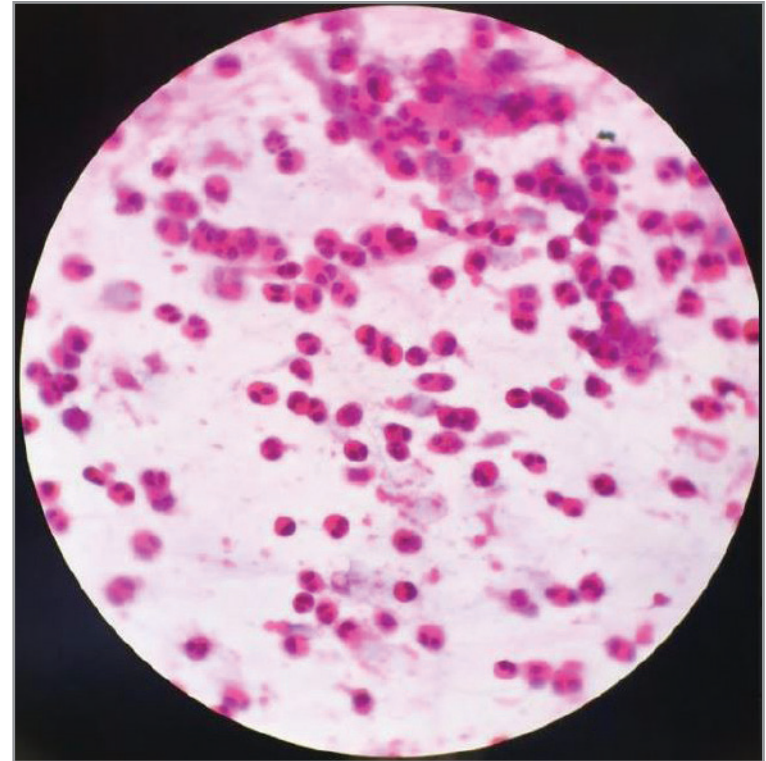

Figure 2. BAL microscopic examination, eosinophil 79\%.

was started. On the second day of treatment, EOS decreased to $0.1 \%-0.02 \times 10^{9} / \mathrm{L}$. His symptoms disappeared completely; there was no need for nasal oxygen $\left(\mathrm{O}_{2}\right.$ saturation> 95). The antibiotic and antifungal treatment was discontinued when the patient was afebrile for 48 hours. The patient, with significant improvement on lung X-ray, was discharged with the recommendation of decreasing doses of steroids.

\section{DISCUSSION}

In this case, we presented a patient with organ-limited hypereosinophilia, characterized by respiratory tract involvement, which we define as EARR + CEP overlap. Besides, the primary and secondary causes of hypereosinophilia should be investigated, especially if there is a history of nasal polyposis and chronic eosinophilic pneumonia, and if there is organ damage or dysfunction after primary immunodeficiency causes are excluded. We wanted to emphasize the importance of bearing EARR in mind. We think that this case report is vital in terms of showing EARR and CEP cases, which may rarely be seen in childhood.

More than 1500 cells $/ \mu$ is accepted as eosinophilia with the potential for tissue infiltration and hypereosinophilia (6). We noticed that in some patients with EA-CRS/NP, this potential pulmonary tissue infiltration could be demonstrated by radiological imaging. We defined this group as EARR (7). EARR is the most severe clinical form of adult-onset eosinophilic asthma and is mainly seen in aspirin exacerbated respiratory disease (AERD) and EA-CRS/NP patients. These patients had the most severe form because they had very high eosinophil levels and radiological infiltrations associated with eosinophilia. They were all dependent on systemic corticosteroids, and only a small percentage were able to discontinue corticosteroids (7).

One of the hallmarks of chronic rhinosinusitis with nasal polyps (CRS/NP) is enhanced tissue eosinophilia compared to healthy sinonasal tissue (10). The unified airway hypothesis also suggests that disease in the upper and lower airways is related. Patients with CRS/NP and asthma have significantly more severe radiological evidence of sinonasal inflammation (11). This is supported by a previous study in which CRS patients with asthma had more severe sinonasal inflammation and were more likely to have nasal polyps than CRS patients without asthma (12). Also, another study found a significant positive association between the asthma severity and both the degree of sinonasal inflammation and the likelihood of having nasal polyps (13). Thus, these observations led to the hypothesis that eosinophils are more highly activated in the new phenotype than CRS/NP. We could see the infiltration radiologically on thorax CT if the degree of sinonasal inflammation could be reflected in the radiological appearance (PNSCT) or even lead to nasal polyps by releasing their granule contents, and the increased eosinophils could lead to eosinophilic infiltration. In our case, there were abnormal radiological findings together with nasal polyposis and severe hypereosinophilic asthma. It was revealed that these abnormal findings were secondary to eosinophilic infiltration by bronchoalveolar lavage (BAL) examination. This result was confirmed with complete radiological recovery with systemic steroids.

In differential diagnosis, eosinophilic lung diseases which are a diverse group of pulmonary disorders associated with peripheral or tissue eosinophilia (drug-induced eosinophilic pneumonia, Loffler's syndrome, hypereosinophilic syndrome (HES) (primer, seconder, and idiopathic), lymphocytic HES (also called subgroup of secondary HES), allergic bronchopulmonary aspergillosis, microscopic polyangiitis, granulomatosis with polyangiitis (Wegener's), eosinophilic granulomatosis with polyangiitis (EGPA), 


\begin{tabular}{|c|c|c|c|}
\hline Hücre Dağııımı & $\begin{array}{c}\text { Tüm Hücre } \\
\text { Kapısı }\end{array}$ & $\begin{array}{c}\text { Lenfosit } \\
\text { Kapısı }\end{array}$ & $\begin{array}{c}\text { T Hücre } \\
\text { Kapısı }\end{array}$ \\
\hline Blast (CD45.......) & - & - & \\
\hline Diğer (CD45 negatif & - & - & \\
\hline Nötrofil & $\% 89$ & & \\
\hline Monosit & $\% 3$ & & \\
\hline Eozinofil & - & & \\
\hline Lenfosit & $\% 8$ & $\% 100$ & \\
\hline NK (CD56) & $\% 1$ & $\% 12$ & \\
\hline B (CD19) & $\% 4$ & $\% 50$ & \\
\hline $\mathrm{T}(\mathrm{CD} 3)$ & $\% 3$ & $\% 38$ & $\% 100$ \\
\hline TCR ab & & & $\% 80$ \\
\hline TCR gd & & & $\% 20$ \\
\hline
\end{tabular}

\begin{tabular}{|l|l|}
\hline \multicolumn{2}{|l|}{ Referans Aralığı (\%) (Erişkin) } \\
\hline Lenfosit \%100 \\
\hline T (Lenfosit) & $56-82$ \\
\hline B (Lenfosit) & $7.7-22$ \\
\hline NK (Lenfosit) & $6-33$ \\
\hline
\end{tabular}

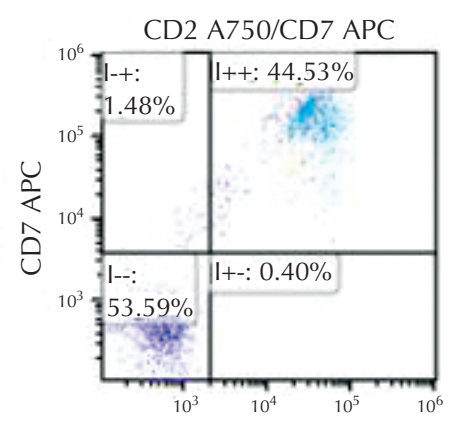

CD2 A750

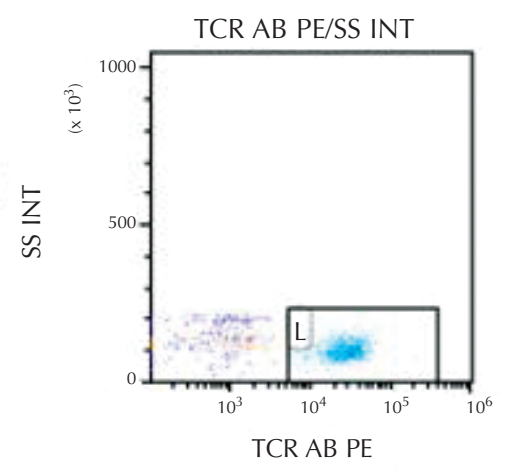

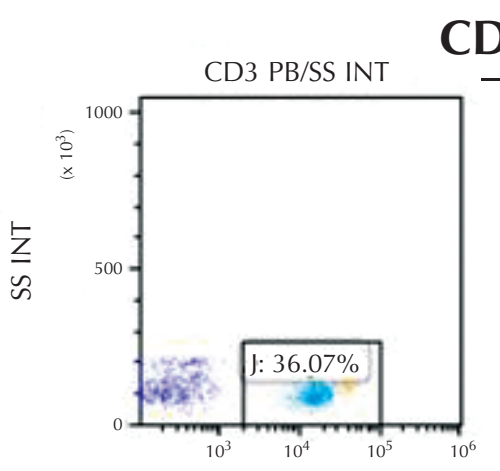

CD3 PB

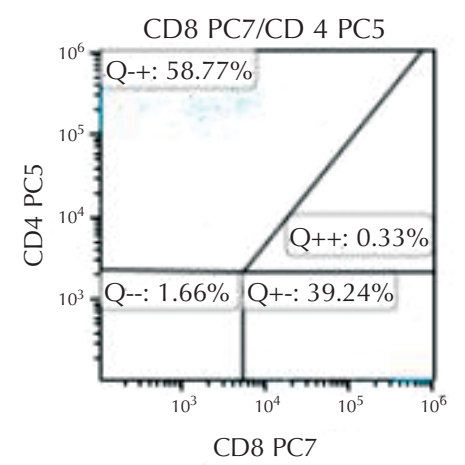

CD45 KO/SS INT

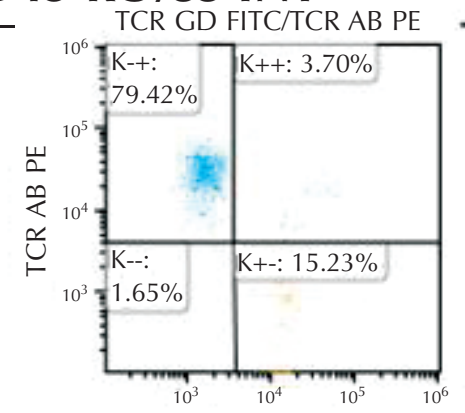

TCR GD FITC

I! i

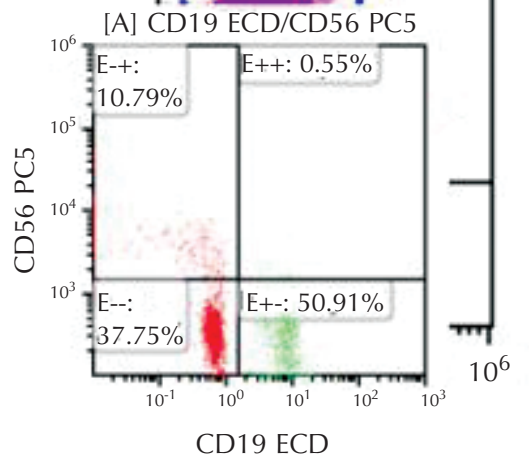

Figure 3. Peripheral blood immunophenotyping (CD4/CD8 ratio was 58/39 in TCRAB + T cells).

malignancies (lymphoproliferative, myeloproliferative, and solid organ), and collagen vascular diseases (14-16) have been excluded in the case with clinical and laboratory results in the case (Table 2). Coincidental bacterial or viral pneumonia may occur in patients with asthma and eosinophilia. In our patient, pneumonia had been ruled out using the patients' clinical and laboratory findings (BAL cul- ture, sputum culture), and corticosteroid response without antibiotics. The patient was accepted as EARR + CEP overlap after making all these differential diagnoses. We, therefore, believe that this specific group (EARR) can be considered as a phenotype of severe eosinophilic asthma and an organ restricted hypereosinophilic condition like CEP. CEP was diagnosed based upon the combination of greater than 
two weeks of respiratory symptoms, BAL and/or blood eosinophilia (usually with BAL cell count differential $>40 \%$ or serum eosinophils $>1.000 / \mathrm{mm}^{3}$ ), pulmonary infiltrates with a peripheral predominance and exclusion of other known causes of eosinophilic lung diseases (9). This patient also met the diagnostic criteria for CEP.

The other primary and secondary causes of hypereosinophilia were ruled out in this case. We think that this case is CEP, a disease accompanied by organ-restricted hypereosinophilia, and EARR overlap. The case is accompanied by fever and high CRP, which are seen in typical CEP cases but are not usually seen in EARR. Nasal polyposis and severe asthma, seen in EARR but not detected very much in CEP, accompanied. CEP and EARR properties are shown in Table 3. CEP seems to be more dominant in this overlap diagnosis because fever is accompanied in the case, CRP and sedimentation are high, and responses to systemic steroids are very good in EARR, but recovery is not expected as fast as in this case. The other point is that similar to atopic dermatitis, atopic rhinitis, and atopic asthma, there is also an allergic march among this group of patients as CRS nasal polyps, asthma, AERD; however, it does not always have a particular order and may have variations (11). Our study showed that the end stage of this eosinophilic march consists of eosinophilic pulmonary infiltrates, depending on the severity of eosinophilic inflammation (7). However, in the literature, patients with EARR and extrapulmonary involvement have been very rarely identified (17). Although speculative, it suggests that this group can be called EARR and meets the diagnostic criteria for idiopathic HES, which may affect the organ functions because of peripheral hypereosinophils by going to tissues through extrapulmonary eosinophilic chemoattractants.

In conclusion, here we presented a case of EARR + CEP overlap, accompanied by organ-limited hypereosinophilia, with detailed differential diagnosis. It should be kept in mind that EARR/CEP overlap might have the potential to become systemic due to possible eosinophil chemoattractants in other organs and that it may turn into idiopathic HES or EGPA.

\section{CONFLICT of INTEREST}

The authors reported no conflict of interest related to this article.

\section{AUTHORSHIP CONTRIBUTIONS}

Concept/Design: All of authors

Analysis/Interpretation: IY, GPÇ, BA

Data Acquisition: All of authors

Writing: IY, GPÇ, BA

Critical Revision: IY, MK, GPÇ

Final Approval: iY

\section{REFERENCES}

1. Amelink $M$, de Groot $\mathcal{C}$, de Nijs $S B$, Lutter $R$, ZwindermanAH, Sterk PJ, et al. Severe adult-onset asthma: a distinct phenotype. I Allergy Clin Immunol 2013; 132(2): 336-41.

2. Fajt ML,Wenzel SE. Asthma phenotypes and the use of biologic medications in asthma and allergic disease: the next steps toward personalized care. I Allergy Clin Immunol 2015; 135(2): 299-310.

3. de Groot JC, ten Brinke A, Bel EHD. Management of the patient with eosinophilic asthma: a new era begins. ERJ Open Res 2015; 1(1): 00024-2015.

4. Yilmaz I, Terı M. Asthma management: a new phenotypebased approach using presence of eosinophilia and allergy. Allergy 2017; 72(10): 1587-9.

5. Yılmaz I, Turk M, Bahceciog/u SN. Eosinophilic asthma with nasal polyposis march: is aspirin-exacerbated respiratory disease the last station? I Allergy Clin Immunol Pract 2017; 5(6): 1808-9.

6. Roufosse F, Weller PF. Practical approach to the patient with hypereosinophilia. I Allergy Clin Immunol 2010; 126(1): 39-44.

7. Yılmaz I, Bahçecioğlu SN, Türk M, Tutar N, Oymak FS, Gülmez $i$. Last station in the eosinophilic asthma with chronic rhinosinusitis and/or nasal polyposis march: Eosinophilic asthma with radiological findings associated with blood eosinophilia. J Asthma 2019; 56(2): 111-7.

8. Cottin V. Eosinophilic lung diseases. Clin Chest Med 2016; 37(3): 535-56.

9. Crowe $M$, Robinson D, Sagar M, Chen L, Ghamande $S$ Chronic eosinophilic pneumonia: clinical perspectives. Ther Clin Risk Manag 2019; 15: 397-403.

10. Van Zele T, Claeys S, Gevaert P, Van Maele G, Holtappels $G$, Van Cauwenberge $P$, et al. Differentiation of chronic sinus diseases by measurement of inflammatory mediators. Allergy 2006; 61(11): 1280-9.

11. Stevens $W W$, Peters AT, Hirsch AG, Nordberg CM, Schwartz BS, Mercer DG, et al. Clinical characteristics of patients with chronic rhinosinusitis with nasal polyps, asthma, and aspirin-exacerbated respiratory disease. I Allergy Clin Immunol Pract 2017; 5(4): 1061-70. 
12. Pearlman AN, Chandra RK, Chang D, Conley DB, TripathiPeters A, Grammer LC, et al. Relationships between severity of chronic rhinosinusitis and nasal polyposis, asthma, and atopy. Am J Rhinol Allergy 2009; 23(2): 145-8.

13. Lin DC, Chandra RK, Tan BK, Zirkle W, Conley DB, Grammer $L C$, et al. Association between severity of asthma and degree of chronic rhinosinusitis. Am I Rhinol Allergy 2011; 25(4): 205-8.

14. Lefèvre G, Ackermann F, Kahn JE. Hypereosinophilia with asthma and systemic (non-vasculitic) manifestations: eosinophilic granulomatosis with polyangiitis or hypereosinophilic syndrome? Autoimmun Rev 2017; 16(2): 2089 .
15. Valent P, Klion AD, Horny HP, Roufosse F, Gotlib I, Weller $P F$, et al. Contemporary consensus proposal on criteria and classification of eosinophilic disorders and related syndromes. J Allergy Clin Immunol 2012; 130(3): 607612.e9.

16. Gotlib J. World Health Organization-defined eosinophilic disorders: 2014 update on diagnosis, risk stratification, and management. Am J Hematol 2014; 89(3) :325-37.

17. Ameratunga R, Steele R.J Eosinophilic granulomatosis with polyangiitis (Churg-trauss vasculitis) presenting as Samter's triad. J Allergy Clin Immunol Pract 2018; 6(1): 280-2. 